\title{
Maintenance and Development of Intangible Cultural Heritage of Minangkabau People Through Figures of Speech
}

\author{
Hasanuddin WS \\ Faculty of Languages and Arts, Universitas Negeri Padang \\ hasanuddinws@gmail.com
}

\begin{abstract}
This research article contained a discussion about efforts to maintain and develop an intangible cultural heritage of Minangkabau people in the speech, that is speak using figurative language. The figure of speech used by Minangkabau people is spoken in the form of a traditional phrase (proverbs). This research is a qualitative research. The main data is obtained through recording, transcribed, and translated. The main data has documents. Supporting data is obtained through observation, interview, and recording. The main data is the traditional Minangkabau expression categorized under the Minangkabau formulation as the owner of the tradition by referring to the concept of traditional Keyzer's traditional expression categorization. The study of Minangkabau speaking in figure of speech language in the form of a traditional expression is based on a language pragmatic perspective using the Jakobson, Halliday, and Oktavianus concepts. The study of the maintenance and development of the tradition speak in figure of speech language of Minangkabau people using the concepts put forward by Danandjaja, Fanany and Fanany, and Hasanuddin WS. Based on the research findings, traditional Minangkabau expressions can be categorized into at least five types, namely animal category; plants; about man; members of relatives; and limb function. These five categories are used Minangkabau people to speak and effective for the following things, namely to give a warning; give advice; expressing feelings and thoughts; affect the other person; order and or prohibit; reinforce intent; asking or begging for something; as well as satirical. Maintenance and development of intangible cultural heritage of Minangkabau people speak in figure speech of language must be done in the educational process by considering aspects of reification, manipulation, fragmentation, and individualization. Speaking in the figure of speech language as the intangible cultural heritage of the Minangkabau people is important to be preserved and developed because based on the pragmatic perspectives the language is able to function as a teaching point in developing community integrity, exercise social control, integrate shared forces that are divided for social solidarity, group identity, and maintain communal harmony.
\end{abstract}

Keywords--maintenance, development, intangible cultural heritage, speech, figure of speech language, Minangkabau traditional expression

\section{INTRODUCTION}

Unlike Javanese or Sundanese speakers, for example, the Minangkabau language speakers do not seem to worry too much about the shrinking Minangkabau speakers of the younger generation. Kaswanti ${ }^{i e}$ s research (2016) shows interesting facts about Minangkabau language speakers. Families from the upper middle class to the ethnic Minangkabau in some big cities in West Sumatra who speak in their family using Indonesian and or English and not Minangkabau language do not cause their children are not able to speak in Minangkabau language. Their children are fluent in Minangkabau language. One of Kaswanties findings of why it happens is that outdoors, the children in their daily life, in neighboring neighborhoods, in schools, in markets, and elsewhere "require" that they keep speaking in Minangkabau language.

This finding will add to the Minangkabau people's belief that the extinction of Minangkabau speakers will not happen. Minangkabau people in the traditional expression of the saying "clothes if worn become obsolete, customs if used to be new". That is, the customs will remain awake and sustainable if continued to be used and used by the community. Minangkabau language, as Minangkabau customs if it continues to be used in various types of daily interactions in various activities of life, the extinction of Minangkabau speakers need not be too worried.

The findings of Kaswanti (2016) hereinafter, in relation to Minangkabau speakers found different things compared to families of Javanese or Sundanese ethnic who speak Indonesian and or English at home with their children. The children of the Javanese and or Sundanese ethnic families find it difficult to communicate in the local language of Java or Sundanese. Even those who are daily at home use English, difficult to communicate in the Indonesian language. Many of them are more fluent in speaking and writing in English. This is known through through writing lessons at their school. At the time of writing lessons, children from Javanese and Sundanese families found it difficult to express their thoughts and feelings using the local or Indonesian language.

Although based on the results of such research, it does not mean there is no concern at all about how Minangkabau language is spoken from time to time. Worries about Minangkabau language are in fact more essence, that is, the abandonment of Minangkabau language utterance in various traditional expressions of Minangkabau proverbs, phrases, by the people. Minangkabau people today, not like Minangkabau people of the past. Their proverb 
says "binatang tahan palu, urang tahan kieh" (animals are hammer resistant; humans hold figure speech of language). The Minangkabau people are actually used to delivering noble teachings and counsel through traditional expressions. This is what seems to be abandoned by Minangkabau people today. The tendency of Minangkabau people today to declare everything, including teaching and criticism, is done in a straightforward and spontaneous way. Appointment and social criticism in a straightforward and spontaneous way will lead to a reduction in the level of wisdom and emotional intelligence. This will slowly cause a shift in the pattern and behavior of Minangkabau people who prioritize the wisdom and emotional intelligence in speaking using in his mother tongue toward the intellectual intelligence only.

The traditional Minangkabau phrase is proverbs. A phrase is one of the most valuable Minangkabau worth of intangible cultural heritage. The intangible cultural heritage of Minangkabau traditional expression contains teachings and noble advice. In it is stored local wisdom about how the planting and learning of intelligence and character education to the next generation. If the mastery of Minangkabau speakers decreases in its traditional expression, it is possible that this intangible cultural heritage will gradually disappear and become unknown in the future. This intangible cultural heritage will only be kept as documentation in textbooks or encyclopedias alone. Considering the discomforts of urban lifestyle that often underestimated the traditions of their ancestors, it is necessary to consider and make efforts to maintain and develop the intangible cultural heritage of Minangkabau traditional expressions in the form of proverbs, phrases, and ратеo. Maintenance and development of this intangible cultural heritage are also becoming very important in the future regarding legal cultural recognition. In an "infinite" world, cultural recognition will be legally possible by other countries that have cultural traits there. Legal acknowledgment will be made easier by other countries if the maintenance and development of this intangible cultural heritage is not immediately carried out by the Minangkabau people themselves.

The Minangkabau culture that is to be preserved should not only be related to the thinking of Minangkabau people in the past, but also related to the problems of Minangkabau people today and the future. Some things should be taken seriously. First, the maintenance of culture is related to the effort to keep the culture always new (in accordance with the present). It is the cultural actuality that causes people to live and grow according to the needs and demands of his time. Second, the future development of Minangkabau culture is closely related to the development of thinking among Minangkabau people today. In addition, since the development of Minangkabau culture will be related to issues outside the Minangkabau people, it is also necessary to know the trends of Minangkabau society and other ethnic communities in Indonesia, including the tendency of the world community in this globalized life. In connection with that, before further discussed the alternative maintenance and development of Minangkabau culture of the present and future, it is better traced in advance the cultural conditions and tendencies of Minangkabau people.

The literature review of the social function of Minangkabau people speak in kias language using traditional expression (proverb) is based on the language pragmatic perspective as done by Jakobson (in Teeuw, 2000); Halliday (1985); and Octavian (2015). In addition, the knowledge and local wisdom of the Minangkabau people in speaking languages use the traditional phrase (proverb) as a form of instructional communication refers to a study by Barthes (2003); Danandjaja (1984); Fanany and Fanany (2003); and Hasanuddin WS (2015a and 2016). The kias language used by the Minangkabau people in tradition speaks for the purpose of giving warning; give advice; expressing feelings and thoughts; affect the other person; order and / or prohibit; reinforce intent; asking or begging for something; as well as satirical

In line with the study of the social function of the Minangkabau people in the kias language, there is also a categorization of traditional Minangkabau phrases. This is due to the kinese language spoken by the Minangkabau people for their pragmatic use is a traditional form of expression (proverb). Therefore, this study is a study of oral tradition within the framework of folklore research. The study of the traditional Minangkabau phrase texts was formulated in the view of Minangkabau people as owners of this tradition. In the folklore study, the traditional expression falls within the category of oral folklore. The study of traditional Minangkabau expressions based on the views of the owner community, in this study used the Keyzer concept. Keyzer (1862, and in Danandjaja, 1984) conducted research and categorization of Javanese proverbs based on Javanese view as the owner of a Javanese proverb. Categorization in this way was also developed by Fanany and Fanany in formulating the framework of the Malay proverb (2008). The same is done by Gibbs (1995; and in Fanany and Fanany, 2008) through his scientific publication on the Psychology bulletin entitled "What Proverb Understanding Reveal about What People Think."

\section{METHOD}

The research on which the article is based is qualitative, the research done by not using numbers and statistical data processing, but preferring the appreciation of the researcher on the interaction between the concepts being studied empirically. A study conducted with the intent to understand the phenomenon of what is experienced by the subject of research such as behavior, perception, motivation, action, holistically, with a natural special context, and by utilizing scientific methods.

This research was a research that produces descriptive data in the form of written or oral words of people and behavior that can be observed, depending on the observation on humans, both in the region and in terminology. This 
research prioritized the natural setting and is done to present the social world, and its perspectives in the world in terms of concepts, behaviors, perceptions, and human issues being studied.

Data in this research were data of social function based on pragmatic perspective speaking of Minangkabau people in figurative language using traditional expression (proverb) and data of traditional oral tradition category of Minangkabau (proverb) based on formulation of the owner community. Data collection was done in two stages. The first stage was inventorying stage through literature study (document analysis) and field study (recording). If the data is spoken directly by the informant, the informant's speech is recorded using a tape recorder. The recordings are transcribed into written form. The result of transcription (substitution of alphabet) was subsequently transliterated (transfer of language) from the Minangkabau regional language into Indonesian. The second stage was the collection of data on the narrative story-telling environment (life view and philosophy, as well as the living values of the speakers' community associated with the oral tradition of traditional Minangkabau proverbs) data collected through recording, observation and interview techniques.

\section{FINDING AND DISCUSSION}

The findings of this study, showing that the traditional expression of the Minangkabau proverb based on the formulation of its owner community, fulfills the criteria as did Keyzer (Danandjaja, 1984, p. 30). The traditional expressions of Minangkabau proverbs can be categorized in at least six categories. The five categories of traditional Minangkabau expressions are (a) animal or fauna categories (fish, birds, insects, mammals, other animals); (b) plants or flora (trees, fruits, and other plants); (c) concerning man; (d) members of a relative; (e) limb function.

Based on the categorization of the traditional expression of the Minangkabau proverb that is found, it seems so close to the relationship between Minangkabau people and the environment in which they live their lives and lives. They have a very good knowledge of the animals and plants that live in their environment. Characteristics of animals and plants they use as a speech to reprove or satirize the other person, for example. The phrase Mamintak suaro ka anggang, mamintak dayo ka gajah (Asking voice to horn, ask for power to elephant) and expression Gadang buayo in muaro, gadang garundang in kubangan, samuik barajo in liangnyo (big crocodile in estuary, big tadpole in puddles, ants become kings in their holes) affirms that the knowledge of the animal characteristics they use in their traditional expressions is well known. Ask for the sound of the hornbills because it has the loudest and loudest sound, and not the other birds. To the elephants where they ask for energy. Ask something that has, not the other way around. It is also a message that "always be careful to all rulers who are in its territory." To crocodiles have to be careful because it is dangerous, but to crocodiles in the estuary should be extra careful because the crocodile was in the habitat. Likewise to the ants in the burrow because the ants become very protective and aggressive to anyone who is considered to interfere with their holes / nests. The findings of this study show that the categorization of traditional Minangkabau expressions is broader than Keyzeres (1862) findings of traditional Javanese expressions.

The research findings on local wisdom speak using the traditional expressions of Minangkabau (proverbs) based on the pragmatic perspectives of language Jakobson (in Teeuw, 2000), Danandjaja (1984), Halliday (1985), and Octavianus (2015), are considered important by Minangkabau people as a communication system. Talking using the traditional expression of the proverb is seen by Minangkabau people as a knowledge and local wisdom in speaking for a particular purpose. Minangkabau people will feel comfortable speaking using the traditional expression of proverbs, among others to (a) rebuke or warrant; (b) to advise; (c) expressing thoughts and feelings; (d) influence; (e) order and prohibit; (f) reinforce intent; (g) asking for something or pleading; and (h) insinuating.

To give a warning or admonish the other person, they can use the traditional expression of the following proverbs, Arang kareh bak taji, tulang bak kanji ("Hard sounds like spurs, bone like kanji"; Do not behave arrogantly); or Pandang anak tenggang minantu ("Keep the child, watch the son-in-law"; Do not choose). To admonish, the following traditional expression of the proverbs they often use, Jan manapiak aie di dulang, malantiak ka muko surang ("Do not tap water on the bone, splashing on your own face" Do not open the family's disgrace, yourself will also get embarrassed; or Gabak kok indak jadi ujan, bumi jo langik dapek malu ("Cloudy if it does not rain, the earth and the heavens can be ashamed"; if anyone has made a pledge, it must be proven that he and his family should not be ashamed). To express thoughts and feelings, the following proverbs they use, Dek lamo lupo, dek ragam ragu ("For long forgotten, for much doubt"; something human); or Asa lai ati samo amuah, kariang lautan kito nanti ("The origin of our hearts is like, dry our seas later"; waiting for a long time is not a problem as long as it is equally faithful). To influence, the following proverbs are examples Elok diambiak jo etongan, buruak dibuang jo mupakaik ("Well taken by calculation, badly discarded by consensus"; Look again, whether the decision has been taken carefully and calculated); or Buruak sabatang dicateh, buruak sarumpun dicabuik ("Bad trees are felled, bad clumps are lifted" whether they are acting in context). To enjoin and ban, the following proverb expressions may be used Papek dilua runciang di dalam, talunjuak luruih kalingkiang bakaik ("Exactly outside the pointed inside, pointing finger straight pinky"; Do not betray); or Tibo di mato jan dipiciangan, tibo di paruik jan dikampihan ("Until the eyes are not closed, until the stomach is not deflated"; be firm and fair). To reinforce the intent, this proverb is used Mancancang balandasan, malompek basitumpu ("Chop based, leapfrogged" This work is based on certain rules); or Panjang aka nak malilik, 
panjang kecek nak mangabek ("Root length wants to wrap, long words want to tie"; we want a simple and clear, do not be convoluted). To request something or request, here's a sample proverb used Tagisia dek ka naiak, tasingguang dek ka turun, awak nan indak mansingajo, anta inyo tagak di janjang ("Shifted time will rise, offense will come down, we are unintentional, whether he is at the level"; apology, delivered in public places in general, not to a certain person); or Badando jo ameh nan abih, bapancuang jo padang nan ilang ("Fined with exhausted gold, beheaded with a lost sword") The plea for the matter to be settled peacefully in a kinship manner not through laws and regulations). To insinuate, the following proverbs they usually use Dapek gadiang batuah, tacampak tanduak kabau mati ("Can be a thunderbolt, thrown dead buffalo horns"; Can new friends, old friends not remembered again when the old friend has a lot of help); or Gadang maimpok, panjang melindih, laweh nan manyaok ("Great overwrite, long overlap, broad cover") The nature of a person (ruler) who wants to enslave others in all things).

Based on this, the oral literature of traditional Minangkabau proverbs, should be regarded as a communication system that gives messages regarding past rules, ideas, memories, memories, or decisions that are believed. Therefore, as Barthes (2003, p. 14) notes that belief in something (the values of wisdom that are believed to be true) contained in the work of an element of tradition, is not an object, concept, or idea, but a symbol in the form discourse. Such symbols are not always in written form, but can also be verbal speeches, objects, or certain tools. In the urban community the symbol can be in the form of pictures, movies, and others. This element is not an object, but can be represented by objects.

The belief in the truth of the values of wisdom and wisdom will apply universally, but the stimulus of traditional expressions will depend on the social, cultural, and geographical conditions of the community. A traditional Minangkabau phrase is not necessarily acceptable in other societies. However, as universal, it is possible that the values of wisdom in the traditional expression of the maxim can be accepted by a wider group of people. Nevertheless, the belief in it will be stronger if more and more realities support it, including continuous inheritance through various mass media channels such as newspapers, magazines, television and film.

Human life, and in itself human relations, is dominated by beliefs. One's attitude toward something is determined by the conviction that is within him. However, contact and acquaintance with something can generate new beliefs based on existing beliefs. He may be different from the previous one and it is possible that the new belief is against the previous conviction. If it grows and develops, people s belief in the values of wisdom contained in the traditional expression of the proverb will be accepted as the truth. Communities cannot be blamed for their beliefs because no other community groups are harmed, even the belief in those values can serve as local knowledge and wisdom for the solidarity and integrity of the group. At this stage, the oral literature of traditional Minangkabau proverbs can function as theorem in science.

Minangkabau people live in Indonesia, grow, and grow together with people from various other ethnic as siblings and countrymen. Therefore, the maintenance and development of culture, including the desire to nurture and develop Minangkabau culture, lies in the framework of cultural process that includes aspects of the nation's life. Cultural maintenance and development should be sought in such a way that it is not seen as a threat to other cultural support groups. Maintenance and development of the culture must be oriented to efforts to foster a sense of self-worth and the desire to be appreciated by others. The maintenance and development of culture is aimed at the owners of cultures that are nurtured and developed to feel strong, capable, competent, independent, and free in the eyes of the world. Next is desire to gain reputation, prestige, and appreciation from the outside. It leads to self-esteem, cultivation of cultural pride, patriotism, deprivation of inferiority from other nations or tribes, and has a useful sense for the world. With such a foundation and principle of maintenance and development, especially for the case of Indonesia whose people are so diverse, the maintenance and cultural development with the above-mentioned principles, has minimized the emergence of conflicts between ethnic or ethnic groups.

There are at least four main pillars or four basic factors (see also Poespowardojo, 1984 and 1993) to be considered for the purpose of maintaining and developing culture. These four factors are (1) human as individual, (2) environment, (3) equipment, and (4) community. These four factors must be linked and considered in the effort to preserve and develop Minangkabau culture.

As an individual, man is the determining factor in nurturing and developing culture, for he is not only a supporting subject but also the creator and purpose of the preservation and development of that culture. In relation to this discussion, the thing to be understood is how the Minangkabau's quality as individuals. What is the average level of creativity of Minangkabau people, especially as individual humans. Bachtiar (1992) argues that human creativity is the most important thing to grow. Things to avoid that creativity is not killed but produces creativity is a condition in which humans living in a culture are not confined by their own cultural traditions so incapable of thinking other than the way of thinking of their cultural traditions. On the other hand, the thing that should also be avoided is the freedom that is too great that seems to know no bounds. This condition of freedom tends to produce anarchy in society and culture.

The environment, intended as a universe of the cosmos. Environment is not solely a means for human survival, but also as a field that allows human beings to struggle to live through their works so that it appears the structural relationship between man and his environment. Through this way is how the Minangkabau attachment to the 
environment. To preserve and develop its culture, Minangkabau people must have the sympathy and solidarity of human beings to maintain the continuity and safety of their environment. Is the philosophical "Alam takambang jadi guru" (nature of spread out being a teacher, (will be) held and run by Minangkabau people and Minangkabau people of the future? Can the Minangkabau now and the future believe in their proverbs, adage, or customary philosophy? Do they still understand and want to understand with all that? In other words, do they still believe in their customs, with what their parents and their predecessors once believed?

Equipment can be referred to by other terms as technology. Some anthropologists judge that humans will display their dignity as human beings insofar as they are capable of creating the means to enrich their world. How technology is placed and viewed by Minangkabau people, or perhaps with the opposite question, how do Minangkabau people view and put technology in their survival? Maintenance and development of culture impossible to run perfectly without the mastery of technology by human supporters of that culture.

Community is the result of interaction among individuals who are members of society. Any institution, interpretation, works of individuals of any unique and original nature will disappear if not accommodated in the collectivity, articulated into organic, organic, and converted inheritance. This can be interpreted as follows, whether the work that has been achieved by the Minangkabau people (as a tribe of the nation) has been poured and inherited in the order of life of the people?

There is no other way, education is the most appropriate means to nurture and develop culture. Education as a venue for the maintenance and development of culture, including the preservation and development of Minangkabau culture, will only be meaningful as long as education embodies what is the ultimate goal of culture that is humanization. What humanization means here is an attempt to instill human and humanitarian value into the educational process through the four basic factors mentioned earlier.

Based on an understanding of the objective reality conditions of Minangkabau people today, education can be programmed in such a way. Through the educational program, the desire to preserve Minangkabau culture is deemed worthy to be maintained because it contributes to the integrity of Minangkabau people can be realized through educational institutions. In this case, if the attitude and culture of openness (to change and renewal) that the Minangkabau have so long been regarded as a culturally appropriate aspect, educational institutions can formulate this cultural aspect into their educational programs.

Culture and philosophy of life of the Minangkabau people much embodied in the expression and proverbs of his community. The phrase which reads "sakali aie gadang, sakali tapian barubah" (once flood, once the beach is changed) and "patah tumbuah, ilang baganti" (broken growing, lost change) reminds that Minangkabau people are always ready to accept change. Change the inevitable part of the journey and the development of society. Minangkabau people are not worried about change because Minangkabau people have an open attitude, pragmatic, and oriented contemporaries. Minangkabau people always improve, renew, and perfect the customs so that in accordance with the era. The analogy is the Minangkabau people who always develop their culture, do not worry with the changes that occur. To welcome the future with this globalized world, the Minangkabau's open attitude is an extraordinary capital base. Thus, the cultural aspect of the Minangkabau's openness is worth keeping and developing. In contrast, attitudes and cultures while the Minangkabau people are quick to feel satisfied and easily give up, "just like the deck of the craft of the craft doh" (not completed only by ourselves), and assume everything is easy "Dima tumbuah di situ disiangi" (where grow there was cleaned) seems to need to be formulated to be nurtured and developed in educational programs.

To formulate what is appropriate and what is less worthy of the cultural aspect, the Minangkabau can learn from the experience of the people. The reconstruction of their own cultural form (idea culture or culture system, social system (activities), and artifacts) is not wrong if done by Minangkabau people. The "loneliness" and "alienation" felt by Minangkabau people lately, will make it easier for the Minangkabau people to fully understand what is really to be preserved from the cultural aspect. Cultural aspects that need to be nurtured and then developed are cultural aspects that are able to meet the basic needs of Minangkabau people, namely the need for self-esteem (read: existence). Every human being or group of people has self-esteem and desires respect from others. It first appears in the human and human groups ${ }^{\text {ee }}$ desire to be strong, capable, competent, independent and free in the eyes of the world. Furthermore, want to gain reputation, prestige, and appreciation from outsiders. Self-esteem as value is not a luxury that is impossible to achieve (see how Malays in the Peninsula reach its dignity, so in the various aspects of life today, Malays in the Peninsula can walk with their heads tied up against other ethnicities, or study intellectuals Minangkabau of the past that "releases" its Minangkabau nature to become Indonesian human being who Indonesia culture, or even to become a human citizen of the world that world culture). These values are needed as a foundation for fostering the pride of collectivity, patriotism, depriving people of low self-esteem of ethnic or other nations, and having a useful sense for the world. Finally, the maintenance and development of culture through education leads to self-actualization.

Maintenance and development of Minangkabau culture concerning Minangkabau self-development. Therefore, the maintenance and development of Minangkabau culture must be in accordance with the abilities and talents of the Minangkabau people. In addition, the maintenance and development must be oriented to create the world of 
Minangkabau into a vast world, Minangkabau people's perception opened greater, while human freedom must get a deeper dimension.

In its implementation, the educational institution as the organizer of the maintenance of culture should be able to identify the Minangkabau tradition culture. The ways and habits of the Minangkabau people are destructive and inhibit the progress that needs to be minimized. Where are the ways and habits of constructive society that are worthy of being maintained and continue to be developed, even to be donated into national culture. Another principle that is also important held by educational institutions is the elements of culture and civilization from the outside should be accepted as far as not threatening personality or cultural identity and people Minangkabau. For example, the pattern of life of egalitarian society owned by Minangkabau people that allows democracy to run more smoothly should be mixed and developed as the egalitarian pattern of the world community today. In this way, Minangkabau people can "dance with drums that are beaten (rung)" by the world community.

In its concrete form, the Minangkabau culture which is nurtured and developed through the educational institution's approach is ultimately Minangkabau plus minus culture which is believed to be able to move the society dynamically in its life in its time (see also Hadi, 2013 and 2002; Navis, 2002; Fanany, 2008 and 2003, Sayuti, 2015). Minangkabau culture that plus and minus it in the process of maintenance and development must still be able to bring up the identity of the Minangkabau people. Identity is understood as something that can characterize a person or a group of people, or as a distinction between one and the other. Physically, the identity is what it looks like: cultural objects, language and literature, social institutions, and others. Studies of sociology, anthropology, history, linguistics, philology, and some other branches of science are helpful to be able to formulate and explain it. Inwardly, the identity is a human quality: attitudes, ways, and outlook on life, orientation of cultural values, way of thinking, work ethic, belief, and religion. Studies of the humanities, philosophy, and psychology, help to formulate and explain this side. In this section is already seen where should the position of Minangkabau intellectuals in efforts to maintain and develop the culture, including the artists and writers. Through the creative works, for example in the lyrics of modern Minangkabau songs can be inserted traditional expressions by the Minangkabau pop songwriter. Thus, the teachings and noble suggestions will still be heard and understood by their intentions, sung, and spoken. The writers can also use various Minangkabau traditional expressions in various creative works, both in Minangkabau literary works, as well as Indonesian literary works with local colors of Minangkabau.

\section{CONCLUSION}

The maintenance and development of culture, including the preservation and development of the Minangkabau culture of how to pass on the teachings and noble counsels to its future generations, can not necessarily be compiled in a comprehensive, broad-based way, not only for the benefit of the people and Minangkabau people themselves, but also for the interests of national development, the interests of nation-building.

Maintenance and cultural development must be aimed at dealing with the future of society with all its problems and challenges, and therefore it is natural to be oriented forward. Cultural heritage needs to be respected, but in order for the legacy of the past to show its significance for people's lives today, creative interpretations are necessary. This is where the Minangkabau undergraduate community groups can play a maximum role. With these creative interpretations, based on cultural heritage, maintenance and cultural development (read: Minangkabau culture) will be able to provide optimism and instill a sense of pride and confidence in their own ability to overcome the problems.

Maintenance and cultural development through education based on the essence of culture, namely humanization is expected to display a solid identity. The personality of society refers to a simple, straightforward, honest, and responsible attitude of life. In such a level of life, society on the one hand has an acculturative power, which is open to outside cultural elements, selectively accepts it, and is able to integrate it into its culture to reinforce its identity. In addition, it also contains the creative power to learn from the experience and success of other nations and tribes and has the courage to continue to make necessary renewals.

Life does require courage because the challenges are ready to wait, and change is necessary. So that's the culture. Once the flood, once the shore changed. Things that broke soon grow, the lost soon also changed. The power in the way of dealing with and transforming that change ultimately raises the belief that change and globalization are not "ghosts" to be feared. Minangkabau people must participate mingle in the frenzy of globalization and not close themselves with a rigid tradition fort. In the hustle and bustle, of course the position of the subject should be targeted by Minangkabau people, and not as an object.

\section{References}

Ali, F. (1995). "Akar Intelektual dan Bayangan Masa Lalu" in Magazine of Genta Budaya Number 1, Volume 1, August until October Edition. Padang: Yayasan Genta Budaya Sumatera Barat.

Bachtiar, H. W. (1992). "Kreativitas: Usaha Memelihara Kehidupan Budaya” in Analisis Kebudayaan, 1 (1). Jakarta: Depdikbud. 
Bakar, Jamil, dkk. (1981). Sastra lisan Minangkabau. Jakarta: Pusat Pembinaan dan Pengembangan Bahasa.

Bakar, Jamil, dkk. (1979). Kaba Minangkabau. Jakarta Pusat Pembinaan dan Pengembangan Bahasa.

Barthes, R. (2003). Mitologi (translation by Christian Ly). Bandung: Dian Aksara Press.

Cholifah. (2003). "Anafora dan katafora pada Wacana Dongeng Anak serta Implikasinya bagi Pembelajaran Bahasa dan sastra Indonesia.” Dissertation. Jakarta: FBS Universitas Negeri Jakarata.

Fanany, I., \& R. Fanany. (2008). Four is Odd Five is Even: The Cognitive Framework of Malay Proverbs. Kuala Lumpur: Dewan Bahasa dan Pustaka.

(2003). Wisdom of the Malay proverbs. Kuala Lumpur: Dewan Bahasa dan Pustaka.

Goodenough, W. H. 1981. Culture, language, and society. California: Cummings Publishing Company.

Hadi, W. (2002). "Menyikapi Terjadinya Krisis Identitas dalam Masyarakat Minangkabau” International Conference Paper "Indonesia in Transition". Padang: Fakultas Sastra Universitas Andalas Padang

(2013). Anak Dipangku Kemenakan di Bim: Sagarobak-Tulak Buah Tangan Wisran Hadi. (Ed. Darman Moenir). Padang: Lembaga Kebudayaan Ranah Padang-Direktorat Sejarah dan Nilai-nilai Budaya Kemendikbud

Hadler, J. (2010). Sengketa tiada putus: Matriakat, reformisme islam, dan kolonialisme di Minangkabau. Jakarta: Freedom Institute

Hasanuddin WS. (2015a). Transformasi dan Produksi Sosial Teks Melalui Tanggapan dan Penciptaan Karya Sastra. Bandung: Angkasa

(2015b). "Kearifan Lokal dalam Tradisi Lisan Kepercayaan Rakyat Ungkapan Larangan tentang Kehamilan, Masa Bayi, dan Kanak-kanak Masyarakat Minangkabau Wilayah Adat Luhak Nan Tigo" in Jurnal Kembara: Jurnal Keilmuan Bahasa, Sastra, dan Pengajarannya 1, (2), 198-204, Malang: Universitas Muhammadiyah Malang

(2018). "Social Function of Tradisional Minangkabau Expression: Local Knowledge and Wisdom in Speech" in Proceeding of Sixth International Conference on Languages and Art (ICLA 2017) Advances in Social Science, Education and Humanities Research (ASSEHR), Volume 148 (p. 195-199).

Honeck, R. P. (1997). A proverb in mind: The cognitive science of proverbial wit and wisdom. London: Lawrence Erlbaum Associate .

Irianto, S. (2016). "Masyarakat Adat dan Keindonesiaan” in Kompas . 10 June 2016, p. 7. Jakarta: Kompas.

Iskandar, N. S., dkk. (1961). Peribahasa. Jakarta: Balai Pustaka.

Mestoko, S., dkk. (1986). Pendidikan di Indonesia dari zaman ke zaman. Jakarta: Balai Pustaka.

Kaswanti, B. (2016). "MEA bagi Kita: Ancaman atau Tantangan?" in Procecedingof National Conference "Kajian Mutakhir Bahasa dan Sastra Indonesia, serta Pembelajarannya menghadapi Masyarakat Ekonomi ASEAN" (ISBN 978-602-14086-8-1). Padang: Jurusan Bahasa dan Sastra Indonesia dan Daerah FBS UNP.

Keyzer, S. (1862). "Een Verzameling van Javaansche Spreekwoordelijk Uitdrukkingen (Satu Himpunan Peribahasa Jawa. Bijragen tot de Taal-, Land-en Volkenkunde van Nederlands Indie. Deel 99 (p. 161-201).

Latief, Ch. N. (2002). Etnis dan adat Minangkabau. Bandung: Angkasa.

Navis, A. A. (1984). Alam terkembang jadi guru: adat dan kebudayaan Minangkabau. Jakarta: Grafiti Press.

Navis, A. A. (2002). "Perkisaran Orientasi Masyarakat Minangkabau dari Masa ke Masa" International Conference Paper "Indonesia in Transition". Padang: Fakultas Sastra Universitas Andalas.

Poepowardojo, S. (1993). Strategi kebudayaan: Suatu pendekatan filosofis. Jakarta: Gramedia.

Poepowardojo, S. (1984). "Refleksi Budaya Mengenai Pembangunan Nasional” in Analisis Kedudayaan IV (2). Jakarta: Depdikbud.

Qodir, Z. (2016). “Masyarakat „Post-Sekuler" in Kompas. 30 Mei 2016 p. 7. Jakarta: Kompas.

Rusyana, Y. (2000). Prosa tradisional: Pengertian, klasifikasi, dan teks. Jakarta: Pusat Bahasa.

Sayuti, S. A. (2015). "Meng-Indonesia" Makalah in Procecedingof National Conference "Kajian Mutakhir Bahasa dan Sastra Indonesia, serta Pembelajarannya menghadapi Masyarakat Ekonomi ASEAN” (ISBN 978-602-140868-1). Padang: Jurusan Bahasa dan Sastra Indonesia dan Daerah FBS UNP.

Taum, Y. Y. (2011). Studi sastra lisan: Sejarah, teori, metode, dan pendekatannya disertai contoh penerapannya. Yogyakarta: Lamalera.

Teeuw, A. (1984). Sastra dan ilmu sastra: Pengantar teori sastra. Jakarta: Pustaka Jaya.

Udin, S. (1993). Seri tradisi lisan nusantara: Rebab pesisir selatan malin kundang. Jakarta: Yayasan Obor Indonesia. 